\title{
PENGARUH PEMBIAYAAN MURABAHAH, MUDHARABAH, IJARAH DAN RASIO NON PERFORMING FINANCING TERHADAP PROFITABILITAS PT BANK BRI SYARIAH TBK
}

\author{
Nanda Suryadi \\ Fakultas Ekonomi dan Ilmu Sosial, Universitas Islam Negeri SUSKA Riau \\ Email : nanda.suryadi@uin-suska.ac.id
}

\begin{abstract}
ABSTRAK
Penelitian ini bertujuan untuk menguji dan menganalisis profitabilitas PT. Bank BRI Syariah Tbk. Adapun beberapa faktor yang dianalisis dalam mempengaruhi profitabilitas adalah pembiayaan murabahah, mudharabah, ijarah, dan rasio non performing financing. Metode analisis data yang digunakan dalam penelitian ini adalah analisis regresi linier berganda, data diperoleh berdasarkan data triwulan yang terdapat di laporan keuangan Bank BRI Syariah dari bulan Januari 2014 sampai dengan Desember 2020. Instrumen pengumpulan data yang digunakan bersumber dari laporan keuangan Bank BRI Syariah. Hasil penelitian ini menunjukan bahwa pembiayaan mudharabah dan rasio non performing financing secara parsial berpengaruh signifikan terhadap profitabilitas, sedangkan pembiayaan murabahah dan pembiayaan ijarah secara parsial tidak berpengaruh signifikan terhadap profitabilitas. Hasil pengujian secara simultan pembiayaan murabahah, pembiayaan mudharabah, pembiayaan ijarah dan rasio non performing financing memiliki pengaruh signifikan terhadap profitabilitas. Dari hasil uji koefisien determinasi dapat diketahui bahwa nilai $R$ Square sebesar 0,396 atau 39,6\%. Hal ini menunjukkan bahwa kemampuan variabel independen dalam penelitian ini untuk menerangkan variabel dependen ialah sebesar $39,6 \%$ dan sisanya $60,4 \%$ dipengaruhi oleh variabel lainya.
\end{abstract}

\section{Kata Kunci : Pembiyaan Murabahah, Mudharabah, Ijarah, Rasio non Performing Financing dan Profitabilitas.}

\begin{abstract}
This study aims to test and analyze the profitability of PT Bank BRI Syariah Tbk. The several factors analyzed in influencing profitability are Murabahah, Mudharabah, Ijarah, and Non-Performing Financing ratios. The data analysis method used in this study is Multiple Linear Regression Analysis, the data is obtained based on quarterly data contained in the financial statements of BRI Syariah Bank from January 2014 to December 2020. The data collection instrument used is sourced from the BRI Syariah Bank Financial Statements. The results of this study indicate that Mudharabah Financing and Non-Performing Financing Ratios partially have a significant effect on Profitability, while Murabahah Financing and Ijarah Financing partially have no significant effect on Profitability. The results of simultaneous testing of Murabahah Financing, Mudharabah Financing, Ijarah Financing and Non-performing Financing Ratios have a significant influence on Profitability. From the results of the coefficient of determination, it can be seen that the Adjusted $R$ Squared value is 0.396 or $39.6 \%$. This shows that the ability of the independent variable in this study to explain the dependent variable is $39.6 \%$ and the remaining $60.4 \%$ is influenced by other variables
\end{abstract}

Keywords : Murabaha Financing, Mudharabah, Ijarah, Non Performing Financing Ratio and Profitability. 


\section{PENDAHULUAN}

Indonesia merupakan negara yang mayoritas penduduknya beragama Islam, kebutuhan masyarakat akan pelayanan yang sesuai dengan ketentuan syariah juga semakin meningkat, salah satu pelayanan yang ada dan menumbuhkan landasan khusus dalam pelaksanaannya adalah bidang keuangan, salah satunya adalah perbankan. Perbankan merupakan lembaga keuangan yang berfungsi menghimpun dana dari masyarakat dalam bentuk simpanan dan menyalurkannya dalam bentuk pendanaan. Perbankan syariah merupakan bagian dari sistem keuangan Islam yang paling maju pesat (Yustati \& Handayani, 2017). Bank syariah pertama kali berdiri pada tahun 1991 dengan nama Bank Muamalat. Hingga saat ini bank syariah terus berkembang dengan signifikan. Dikutip dari website Otoritas Jasa Keuangan per oktober 2020, industri perbankan syariah terdiri dari 14 Bank Umum Syariah dan 20 Unit Usaha Syariah di Indonesia dengan total asset mencapai $\mathrm{Rp}$. 381.846 miliar.

Dengan bertambahnya perbankan syariah di Indonesia dapat memperluas pangsa pasar yang sesuai dengan syariah. Perbankan syariah hingga akhir tahun 2020 terus menunjukkan perkembangan positif dengan asset, pembiayaan yang disalurkan (PYD), dan dana pihak ketiga (DPK) yang terus tumbuh diiringi dengan rasio kinerja utama karena pertumbuhannya yang sedikit melambat. Tidak dapat dipungkiri lembaga keuangan berlomba-lomba untuk menjadi yang terdepan dengan memberikan kemudahan-kemudahan dalam memenuhi kebutuhan baik konsumtif maupun produktif. Rendahnya pangsa pasar perbankan syariah dibandingkan dengan bank konvensional juga dapat mempengaruhi pendapatan perbankan syariah. Hal ini dapat digambarkan bagaimana kinerja perbankan syariah dan salah satunya dapat diukur dengan rasio keungan, yakni rasio profitabilitas.

Profitabilitas merupakan ukuran kemampuan suatu entitas usaha dalam menghasilkan laba. Profitabilitas sangat penting karena profitabilitas merupakan tujuan utama entitas usaha melakukan usahanya. Rasio keuangan yang digunakan adalah Return On Asset (ROA) yang menggambarkan kemampuan perusahaan memperoleh laba melalui semua kemampuan dan sumber daya yang ada. Semakin besar Return On Asset (ROA) yang dimiliki bank, semakin besar pula tingkat keuntungan yang dicapai serta semakin baik pula posisi bank tersebut dari segi penggunaan asset. Dengan kata lain, ROA dapat menunjukkan efesiensi manajemen dalam pengunaan asset untuk mendapatkan keuntungan (Satriawan, \& Arifin, 2016). Alasan dipilihnya Return On Asset (ROA) sebagai ukuran kinerja karena ROA digunakan untuk mengukur kemampuan manajemen bank dalam memperoleh keuntungan secara keseluruhan (Pratiwi, 2012).

Penelitian ini mengambil variabel pembiayaan perbankan syariah yang terkenal yaitu murabahah dari pembiayaan dengan prinsip jual beli, mudharabah dari pembiayaan dengan prinsip bagi hasil serta ijarah dari pembiayaan dengan prinsip sewa.

Diketahui bahwa pembiayaan murabahah dan pembiayaan mudharabah berpengaruh terhadap profitabilitas berdasarkan teori yang dikatakan oleh Riyadi dan Yulianto (2014). Disebutkan bahwa tinggi rendahnya nilai pembiayaan jual beli dan pembiayaan bagi hasil akan berpengaruh terhadap return yang dihasilkan dan akan mempengaruhi profitabilitas (laba) yang didapat. Hal ini dikarenakan bank mengharapkan akan mendapatkan return dan nisbah bagi hasil atau margin keuntungan atas pembiayaan murabahah dan atau pembiayaan mudharabah yang diberikan kepada nasabah yang kemudian bagi hasil atau margin keuntungan tersebut menjadi laba bank syariah.

Selain pembiayaan murabahah, pembiayaan mudharabah dan pembiayaan ijarah, variabel lainnya yang juga dapat mempengaruhi profitabilitas, salah satunya rasio Non Performing Financing (NPF). 
Penyaluran pembiayaan yang berlebihan memungkinkan resiko menjadi pembiayaan bermasalah. Pembiayaan bermasalah dapat dihitung dengan rasio non performing financing. Non Performing Financing (NPF) bertujuan untuk menunjukkan kredit bermasalah dimana rasio NPF umumnya digunakan pada bank syariah. Arah hubungan yang timbul antara NPF terhadap ROA adalah negatif, karena apabila NPF tinggi maka akan berakibat menurunnya pendapatan berpengaruh pada menurunya ROA yang didapat oleh bank Syariah.

Menurut data perbankan yang diakses oleh Otoritas Jasa Keuangan (OJK) salah satu bank syariah di Indonesia adalah Bank BRI Syariah yang merupakan salah satu bank yang menawarkan berbagai jenis produk dan jasa. Bank BRI Syariah juga salah satu yang pertumbuhannya sangat signifikan. Dikutip dari surat kabar elektronik ihram.co.id, 01 Januari 2020) PT. Bank BRI Syariah akan melakukan merger dengan dua perbankan syariah lainnya yakni PT Bank BNI Syariah dan PT. Bank Syariah Mandiri, dimana Bank BRI Syariah akan ditunjuk sebagai bank survivor atau entitas yang berhak menerima penggabungan (survaving entity) usai proses merger dilakukan. Bank hasil penggabungan akan tetap menjadi perusahaan terbuka dan tercatat di Bursa Efek Indonesia dengan tricker code BRIS.

Dikutip dari surat kabar elektronik (katadata.co.id, 30 Desember 2020)PT. Bank BRI Syariah Tbk (BRIS) mencatatkan pertumbuhan laba bersih pada triwulan ketiga 2020 sebesar 238\% menjadi Rp. 190,5 miliar, dibandingkan dengan periode yang sama tahun lalu. Di sisi asset, BRI Syariah tercatat Rp. 56 triliun pada triwulan tiga 2020 , meningkat $51,40 \%$ secara tahunan.

Menurut Azhar dan Nasim (2016) meneliti pengaruh pembiayaan jual beli, pembiayaan bagi hasil, dan non performing finance terhadap profitabilitas (studi kasus pada bank umum syariah di Indonesia Periode 2012-2014). Hasil penelitian menunjukkan bahwa secara parsial pembiayaan jual beli berpengaruh positif terhadap profitabilitas, serta pembiayaan bagi hasil dan non performing finance berepengaruh negatif terhadap profitabilitas. Pengujian secara bersama-sama terdapat pengaruh yang signifikan antara pembiayaan jual beli, pembiayaan bagi hasil dan non performing finance terhadap tingkat profitabilitas.

\section{TINJUAN PUSTAKA}

\section{Bank Syariah}

Menurut Undang-Undang nomor 21 Tahun 2008 menyebutkan bahwa bank syariah adalah bank yang menjalankan kegiatan usahanya berdasarkan prinsip syariah dan menurut jenis nya terdiri atas bank umum syariah dan bank pembiayaan rakyat syariah.

Bank Syariah adalah bank yang beroperasi dengan tidak menghandalkan pada bunga. Bank Islam atau biasa disebut dengan Bank tanpa bunga adalah lembaga keuangan/perbankan yang operasional dan produknya dikembangkan berlandaskan pada Al-quran dan Hadist nabi SAW dengan kata lain, Bank Islam adalah lembaga keuangan yang usaha pokoknya memberikan pembiayaan dan jasa-jasa lainnya dalam lalu lintas pembayaran serta peredaran uang yang pengoperasianya disesuaikan dengan prinsip syariat Islam (Muhammad, 2016).

Berdasarkan pasal 44 UU nomor 21 tahun 2008 tentang perbankan Syariah disebutkan bahwa bank syariah wajib menjalankan fungsi penghimpunan dan menyalurkan dana masyarakat. Bank syariah juga dapat menjalankan fungsi sosial dalam bentuk lembaga baitul maal, yaitu menerima dana yang berasal dari zakat, infak, sedekah, hibah atau dana sosial lainnya. Serta menyalurkan kepada organisasi pengelola zakat. Selain itu, bank syariah juga dapat menghimpun dana sosial dari wakaf dan menyalurkan kepada pengelola wakaf (nazhir) sesuai dengan kehendak pemberi wakaf (wakif). 
Menurut Kasmir (2014) prinsip yang diterapkan oleh Bank Syariah antara lain:

a. Pembiayaan berdasarkan prinsip bagi hasil (mudharabah).

b. Pembiayaan berdasarkan prinsip penyertaan modal (musyarakah).

c. Prinsip jual beli dengan memperoleh keuntungan (murabahah).

d. Pembiayaan barang modal berdasarkan prinsip sewa murni tanpa pilihan (ijarah) atau dengan adanya pilihan pemindahan kepemilikan atas barang yang disewa dari pihak bank oleh pihak lain (ijarah wa iqtina).

\section{Pembiayaan Murabahah}

Pembiayaan murabahah adalah transaksi jual beli, yaitu pihak bank syariah bertindak sebagai pembeli, dengan harga jual dari bank adalah harga beli dari pemasok ditambah keuntungan dalam persentase tertentu bagi Bank Syariah sesuai dengan kesepakatan. Kepemilikan barang akan berpindah kepada nasabah segera setelah peranjian jual beli ditandatangani dan nasabah akan membayar barang tersebut sesuai dengan cicilan tetap yang besarnya sesuai kesepakatan sampai dengan pelunasan (Zainuddin, 2010).

Landasan hukum pengaturan pembiayaan murabahah adalah Fatwa Dewan Syariah Nasional Nomor 04/DSNMUI/IV/2000, bahwa dalam rangka membantu masyarakat guna melangsungkan meningkatkan kesejahteraan dan berbagai kegiatan, bank syariah perlu memiliki fasilitas murabahah bagi yang memerlukannya, yaitu menjual suatu barang dengan menegaskan harga belinya kepada pembeli dan pembeli membayarnya dengan harga yang lebih sebagai laba.

Ada dua jenis murabahah, yaitu (Lestari, 2017) :

\section{Murabahah dengan pesanan}

Dalam murabahah jenis ini, penjual melakukan pembelian barang setelah ada pesanan dari pembeli.
Murabahah dengan pesanan dapat bersifat mengikat atau tidak mengikat pembeli untuk membeli barang yang dipesannya. Kalau bersifat mengikat, berarti pembeli harus membeli barang yang dipesannya dan tidak dapat membatalkan pesanannya.

\section{Murabahah tanpa pesanan}

Murabahah jenis ini tidak mengikat. Pemilik barang (bank) sebelum adanya pesanan disebut murabahah tanpa pesanan. Murabahah tanpa pesanan, maksudnya ada yang pesan atau tidak, ada yang beli atau tidak, bank menyediakan barang dagangannya. Namun, dalam prakteknya di Indonesia yang berlaku adalah bentuk murabahah dengan pesanan.

\section{Pembiayaan Mudharabah}

Pengertian al-mudharabah adalah akad kerja sama antara dua pihak, yaitu pihak pertama menyediakan seluruh modal dan pihak kedua menjadi pengelola keuntungan di bagi menurut kesepakatan yang di tuangkan dalam kontrak. Apabila rugi, kerugian tersebut ditanggung pemilik modal selama kerugian itu bukan akibat dari kelalaian pengelola. Apabila kerugian diakibatkan kelalaian pengelola, pengelolalah yang bertanggung jawab. (Umam, 2013)

Mudharabah adalah transaksi penanaman dana dari pemilik dana (shahibul maal) kepada pengelola dana (mudharib) untuk melakukan kegiatan usaha tertentu yang sesuai syariah, dengan pembagian hasil usaha antara kedua belah pihak berdasarkan nisbah yang telah disepakati sebelumnya. Landasan syariah pembiayaan mudharabah adalah fatwa DSN MUI No.07/DSNMUI/IV/2000 tentang pembiayaan mudharabah. Secara umum mudharabah terbagi menjadi dua jenis, yaitu mudharabah muthlaqah dan mudharabah muqayyadah.

1. Mudharabah muthlaqah adalah bentuk kerja sama antara shahibul 
maal dan mudharib dan cakupannya sangat luas dan tidak dibatasi oleh spesifikasi jenis usaha, waktu dan daerah bisnis. Dalam pembahasan fiqih ulama salafus saleh sering kali dicontohkan dengan ungkapan if'al ma syi'ta (lakukanlah sesukamu) dari shahibul maal ke mudharib yang memberi kekuasaan sangat besar.

2. Mudharabah muqayyadah atau disebut juga dengan istilah restricted mudharabah/specified mudharabah adalah kebalikan dari mudharabah muthlaqah. Si mudharib dibatasi dengan batasan jenis usaha, waktu, atau tempat usaha. Adanya pembatasan ini sering kali mencerminkan kecenderungan umumsi shahibul maal dalam memasuki jenis dunia usaha.

\section{Pembiayaan Ijarah}

Ijarah merupakan transaksi sewa menyewa atas suatu barang dan upah mengupah atas suatu jasa dalam waktu tertentu melalui pembayaran sewa atau imbalan jasa. Ijarah juga dapat diinterpretasikan sebagai suatu akad pemindahan hak guna atas barang atau jasa melalui pembayaran upah sewa, tanpa diikuti dengan pemindahan kepemilikan (ownership/milkiyyah) atas barang itu sendiri (Umam, 2013).

Landasan Syariah pembiayaan ijarah adalah fatwa DSN MUI No.09/DSNMUI/IV/2000 tentang pembiayaan ijarah, menjelaskan bahwa objek ijarah adalah manfaat dari penggunaan barang dan/atau jasa. Serta kewajiban LKS dalam akad ijarah yaitu menyediakan barang yang disewakan atau jasa yang diberikan.

Skema pembiayaan ijarah ialah sebagai berikut:

1. Nasabah mengajukan pembiayaan ijarah ke bank syariah.

2. Bank Syariah membeli/menyewa barang yang diinginkan oleh nasabah sebagai objek ijarah, dari supplier/penjual/pemilik.

3. Setelah dicapai kesepakatan antara nasabah dengan bank mengenai barang objek ijarah, tarif ijarah, periode ijarah dan biaya pemeliharaannya, maka akad pembiayaan ijarah ditandatangani. Nasabah diwajibkan menyerahkan jaminan yang dimiliki.

4. Bank menyerahkan objek ijarah kepada nasabah sesuai akad yang disepakati. Setelah periode ijarah berakhir, nasabah mengembalikan objek ijarah tersebut kepada bank (Karim, 2014).

\section{Non Performing Financing (NPF)}

Non performing financing (NPF) menunjukan kemampuan manajemen bank dalam mengelola pembiayaan bermasalah yang diberikan bank. Pembiayaan bermasalah adalah pembiayaan dengan kualitas kurang lancar, diragukan, dan macet. Semakin besar non performing financing (NPF) mengakibatkan semakin menurunnya Return On Asset (ROA). Menurut Kamus Bank Indonesia, non performing financing (NPF) atau non performing loan (NPL) adalah kredit bermasalah yang terdiri dari kredit yang berklasifikasi kurang lancar, diragukan dan macet (Ma'isyah \& Mawardi, 2015).

Berdasarkan Surat Edaran Bank Indonesia Nomor 9/29/DPbs tanggal 7 Desember 2007, Non performing financing (NPF) dihitung dengan membandingkan jumlah pembiayaan bermasalah dengan total pembiayaan yang dimiliki oleh bank.

Menurut Vanni \& Rochman (2017) penyebab terjadinya pembiayaan bermasalah disebabkan oleh kesulitan-kesulitan keuangan yang dihadapi nasabah, penyebabnya dapat dibagi 2 yaitu:

\section{1) Faktor Internal}

Faktor yang ada didalam perusahaan sendiri dan faktor utama yang paling dominan yaitu manajerial. Kesulitan- 
kesulitan keuangan perusahaan yang timbul karena faktor manajerial dapat diketahui dari kelemahan dalam kebijakan pebelian dan penjualan, lemahnya pengawasan biaya dan pengeluaran, kebijakan piutang yang kurang tepat, penempatan yang berlebihan pada aktiva tetap, permodalan yang tidak cukup.

2) Faktor Eksternal

Faktor-faktor yang ada diluar kekuasaan manajemen perusahaan, seperti bencana alam, peperangan, perubahan-perubahan teknologi dan lain sebagainya.

\section{Profitabilitas}

Rasio profitabilitas merupakan rasio untuk menilai kemampuan suatu perusahaan dalam mencapai keuntungan (Kasmir, 2014). Dalam penggunaan rasio ini dapat menunjukkan suatu efisisensi manajemen perusahaan yang mana hal ini dapat ditunjukkan oleh laba yang dihasilkan dari penjualan dan pendapatan investasi suatu perusahaan.

Indikator yang biasa digunakan untuk mengukur kinerja profitabilitas bank adalah Return on Assets (ROA). Return on assets (ROA) merupakan salah satu rasio profitabilitas yang dapat mengukur kemampuan perusahaan dalam menghasilkan laba dari aktiva yang digunakan. Return on assets merupakan perbandingan antara laba setelah pajak dengan total aktiva yang dimiliki perusahaan. Return on assets (ROA) yang positif menunjukkan bahwa dari total aktiva yang dipergunakan untuk beroperasi, perusahaan mampu memberikan laba bagi perusahaan. Sebaliknya apabila return on assets yang negatif menunjukkan bahwa dari total aktiva yang dipergunakan, perusahaan mendapatkan kerugian. Jadi jika suatu perusahaan mempunyai ROA yang tinggi maka perusahaan tersebut berpeluang besar dalam meningkatkan pertumbuhan. Tetapi jika total aktiva yang digunakan perusahaan tidak memberikan laba maka perusahaan akan mengalami kerugian dan akan menghambat pertumbuhan (Azhar \& Nasim, 2016).

\section{METODE PENELITIAN Jenis Penelitian dan Sumber Data}

Jenis penelitian yang digunakan adalah penelitian kuantitatif. Penelitian kuantitatif adalah suatu proses menemukan pengetahuan yang menggunakan data berupa angka sebagai alat menganalisis keterangan mengenai apa yang ingin kita ketahui (Sujarweni, 2015). Sumber data yang digunakan dalam penelitian ini merupakan data sekunder.

\section{Populasi dan Sampel}

Populasi dalam penelitian ini adalah laporan keuangan Bank BRI Syariah sebagai sumber data. Data yang digunakan sebagai populasi dalam penelitian ini adalah data time series dalam bentuk triwulanan yaitu periode Januari 2014 sampai dengan Desember 2020 sebanyak 28 laporan keuangan. Teknik yang digunakan dalam penelitian ini adalah non probability sampling atau jenuh sampling yaitu pengambilan sampelnya sebanyak jumlah populasinya.

\section{Metode Analisis}

\section{Analisis Statistik Deskriptif}

Statistik deskriptif memberikan gambaran atau deskriptif suatu data yang dilihat dari rata-rata (mean), standar deviasi, nilai maksimum dan minimum. Statistik deskriptif ini menggambarkan data menjadi informasi yang lebih jelas dan mudah dipahami (Sujarweni, 2015).

\section{Uji Asumsi Klasik}

1. Uji normalitas bertujuan apakah dalam model regresi variabel dependen dan variabel independen mempunyai kontribusi atau tidak. Model regresi yang baik adalah data distribusi normal atau mendekati normal. (Ghozali, 2013).

2. Uji multikolinearitas bertujuan untuk menguji apakah suatu model regresi terdapat korelasi antar variabel bebas 
(independen). Dalam penelitian ini, metode yang digunakan untuk mendeteksi multikolinearitas adalah dengan melihat variance inflaction factor dan tolerance value dengan kriteria:

a. Jika nilai tolerance $>0,10$ dan VIF $<10$, maka dapat diartikan bahwa tidak terdapat multikolinearitas pada penelitian tersebut.

b. Jika nilai tolerance $<0,10$ dan VIF $>10$, maka terjadi gangguan pada penelitian tersebut.

3. Uji heteroskedastisitas bertujuan menguji apakah dalam model regresi terjadi ketidaksamaan varian dari residual satu pengamatan ke pengamatan yang lain. Jika varian dari residual satu pengamatan ke pengamatan lain tetap, maka disebut homoskedastisitas dan jika berbeda disebut heteroskedastisitas (Ghozali, 2013). Cara untuk mendeteksi adanya heterokedastisitas antara lain dengan uji glejser yaitu melihat dari tabel coefficient yaitu dari nilai sig $>0,05$ maka tidak terjadi heterokedastisitas.

4. Uji autokorelasi bertujuan menguji apakah dalam model regresi ada kolerasi antara kesalahan pengganggu pada periode-t dengan kesalahan pengganggu pada pada periode $\mathrm{t}-1$ (sebelumnya) (Ghozali, 2013).

\section{Analisis Regresi Linier Berganda}

Analisis regresi linier merupakan teknik statistika untuk membuat model dan menyelidiki pengaruh antara satu atau beberapa variabel bebas terhadap variabel terikat (Basuki, 2016). Adapun rumus yang dipakai disesuaikan dengan variabel yang diteliti:

$Y=a+b_{1} \times 1+b_{2} \times 2+b_{3} \times 3+b_{4} \times 4$

Keterangan :

$$
\begin{aligned}
\mathrm{Y} & =\mathrm{ROA} \\
\mathrm{a} & =\text { konstanta }
\end{aligned}
$$

$\mathrm{X} 1$ = Murabahah

$\mathrm{X} 2$ = Mudharabah

$\mathrm{X} 3$ = Ijarah

$\mathrm{X} 4=$ Non Performing Financing (NPF)

$\mathrm{b} 1=$ Koefisien pembiayaan murabahah

b2 = Koefisien pembiayaan mudharabah

b3 = Koefisen pembiayaan ijarah

b4 = Koefisien rasio non performing financing (NPF)

\section{Uji $\mathbf{R}^{2}$ (Koefisien Determinasi)}

Koefisiensi determinasi $\left(\mathrm{R}^{2}\right)$ digunakan untuk mengetahui presentase perubahan variabel tidak bebas yang disebabkan oleh variabel bebas. Tujuannya adalah untuk menghitung besarnya pengaruh variabel independen terhadap variabel dependen. Semakin tinggi nilai $\mathrm{R}^{2}$ maka semakin besar proporsi dari total variasi variabel dependen yang dapat dijelaskan oleh variabel independen.

\section{Uji t (Parsial)}

Uji t (parsial) digunakan untuk mengetahui apakah sebuah variabel bebas berpengaruh nyata atau tidak terhadap variabel terikatnya (Suharyadi, 2011). Pengujian dilakukan pada tingkat keyakinan 95\% atau tingkat signifikansi 5\% $(\alpha=0.05)$

\section{Uji F (Simultan)}

Uji $F$ digunakan untuk menguji kemampuan variabel bebas terhadap variabel terikat secara bersama-sama (Suharyadi, 2011). Pengujian dilakukan pada tingkat keyakinan $95 \%$ atau tingkat signifikansi 5\% $(\alpha=0.05)$.

\section{HASIL PENELITIAN DAN PEMBAHASAN}

\section{Analisis Statistik Deskriptif}


Tabel 1. Hasil Uji Statistik Deskriptif

\begin{tabular}{lccccc}
\hline & N & Min & \multicolumn{1}{l}{ Max } & \multicolumn{1}{l}{ Mean } & \multicolumn{1}{l}{ Std. Deviasion } \\
\hline MDH & 28 & 49.55 & 70.21 & 58.6507 & 5.62233 \\
\hline MRH & 28 & 0.79 & 7.60 & 4.1005 & 2.36677 \\
\hline IJR & 28 & 0.13 & 7.69 & 3.4184 & 2.87914 \\
\hline NPF & 28 & 1.73 & 4.97 & 3.7150 & 0.76767 \\
\hline ROA & 28 & 0.03 & 1.03 & 0.6496 & 0.29396 \\
\hline Valid N & 28 & & & & \\
\hline
\end{tabular}

Sumber : Data Olahan (2021)

Berdasarkan tabel 1 diatas menunjukkan bahwa $\mathrm{N}$ atau jumlah data dari setiap variabel yang valid berjumlah 28, dari 28 data sampel ROA (Y), nilai minimum sebesar 0.03 , nilai maksimum sebesar 1.03 dari periode 2014-2020 diketahui nilai mean sebesar 0.6496, serta nilai standar deviasi sebesar 0.29396 yang artinya nilai mean lebih besar dari nilai standar deviasi sehingga penyimpangan data yang terjadi rendah maka penyebaran nilainya merata.

Pembiayaan murabahah (X1) dari 28 buah sampel diketahui bahwa nilai minimum sebesar 49.55, nilai maksimum sebesar 70.21, nilai mean dari periode 2014-2020 sebesar 58.6507, serta nilai standar deviasi sebesar 5.62233 artinya nilai mean pembiayaan murabahah periode 2014-2020 lebih besar dari nilai standar sehingga penyimpangan data yang terjadi rendah maka penyebaran nilainnya merata.

Pembiayaan mudharabah (X2) dari 28 buah sampel diketahui bahwa nilai minimum sebesar 0.79 , nilai maksimum sebesar 7.60, nilai mean dari periode 2014-
2020 sebesar 4.1005, serta nilai standar deviasi sebesar 2.36677 artinya nilai mean pembiayaan mudharabah periode 20142020 lebih besar dari nilai standar sehingga penyimpangan data yang terjadi rendah maka penyebaran nilainnya merata.

Pembiayaan Ijarah (X3) dari 28 buah sampel diketahui bahwa nilai minimum sebesar 0.13 , nilai maksimum sebesar 7.69, nilai mean dari periode 20142020 sebesar 3.4184, serta nilai standar deviasi sebesar 2.87914 artinya nilai mean pembiayaan ijarah periode 2014-2020 lebih besar dari nilai standar sehingga penyimpangan data yang terjadi rendah maka penyebaran nilainnya merata.

NPF (X4) dari 28 buah sampel diketahui bahwa nilai minimum sebesar 1.73 , nilai maksimum sebesar 4.97 , nilai mean dari periode 2014-2020 sebesar 3.7150, serta nilai standar deviasi sebesar 0.76767 artinya nilai mean NPF periode 2014-2020 lebih besar dari nilai standar sehingga penyimpangan data yang terjadi rendah maka penyebaran nilainya merata.

Uji Normalitas

\section{Tabel 2. Hasil Uji Normalitas}

\begin{tabular}{ccc}
\hline Sig Hitung & Signifikansi & Keterangan \\
\hline 0.200 & 0.05 & Data terdistribusi normal \\
\hline
\end{tabular}

Sumber : Data Olahan (2021)

Berdasarkan tabel 2 terlihat bahwa nilai signifikan adalah kisaran 0,200. Karena nilai signifikansi lebih besar dari
0,05 maka terdistribusi normal. Dengan demikian, data variabel independen (pembiayaan murabahah, mudharabah, 
ijarah dan NPF) dan variabel dependen (Profitabilitas) merupakan data yang Uji Multikolonieritas

Tabel 3. Hasil Uji Multikolonieritas

\begin{tabular}{lccc}
\hline & Tolerance & \multicolumn{2}{c}{ VIF } \\
\hline Murabahah & 0.390 & 2.562 \\
\hline Mudharabah & 0.363 & 2.752 \\
\hline Ijarah & 0.201 & 4.973 \\
\hline NPF & 0.526 & 1.902 \\
\hline
\end{tabular}

terdistribusi normal.
Berdasarkan tabel 3 diatas, uji multikolonieritas dapat dikatakan tidak terjadi multikolonieritas, karena nilai VIF $<$ 10. Murabahah (X1) sebesar 2.562; Mudharabah (X2) sebesar 2.752; Ijarah (X3) sebesar 4.973 dan NPF (X4) sebesar 1.902. Sehingga dapat disimpulkan data

Tabel 4. Hasil Uji Autokorelasi

\begin{tabular}{ccccc}
\hline Model & R & R Square & Adjusted R Square & Durbin-Watson \\
\hline 1 & 0.679 & 0.486 & 0.396 & 1.274 \\
\hline
\end{tabular}

Sumber : Data Olahan (2021)

Hasil dari Uji Durbin Watson menunjukkan nilai sebesar 1.274. Nilai pada tabel menggunakan nilai signifikansi 0,05 (5\%), jumlah sampel penelitian (n) sebanyak 28 dan jumlah variabel dependen pada penelitian ini tidak terjadi multikolonieritas karena nilai VIF kurang dari 10 sehingga dapat dinyatakan bahwa model tidak mengalami gejala Multikolonieritas.

\section{Uji Autokorelasi}

\section{Tabel 5. Hasil Uji Autokorelasi}

\begin{tabular}{ccccc}
\hline Model & R & R Square & Adjusted R Square & Durbin-Watson \\
\hline 1 & 0.724 & 0.523 & 0.437 & 1.979 \\
\hline
\end{tabular}

Hasil yang kedua setelah peneliti melakukan transformasi Cochrane-Orcutt dengan langkah transform, compute variabel dan memasukkan rumus dengan Lag Y, Lag X1, Lag X2, Lag X3 dan Lag $\mathrm{X} 4$. durbin Watson untuk mendeteksi (k) sebanyak 4, sehingga pada tabel Durbin Watson diperoleh du $=1.7473$ dan 4-du $=2.2527$ maka apabila nilai DW < du $(1.274<1.7473)$ dapat disimpulkan bahwa terjadi Autokorelasi.

adanya gejala autokorelasi atau tidak. Diperoleh hasil nilai Durbin Watson sebesar 1.979. Maka du $<\mathrm{dw}<4$-du $(1.7473<1.979<2.2527)$ sehingga dapat disimpulkan bahwa tidak terdapat gejala autokorelasi. 
Uji Heteroskedastisitas

Tabel 6. Hasil Uji Heteroskedastisitas

\begin{tabular}{ccc}
\hline Variabel & Sig & Keterangan \\
\hline Murabahah & 0.686 & Tidak Terjadi Heteroskedastisitas \\
\hline Mudharabah & 0.718 & Tidak Terjadi Heteroskedastisitas \\
\hline Ijarah & 0.748 & Tidak Terjadi Heteroskedastisitas \\
\hline NPF & 0.992 & Tidak Terjadi Heteroskedastisitas \\
\hline
\end{tabular}

Sumber : Data Olahan (2021)

Dari tabel diatas diperoleh hasil dari uji heteroskedastisitas menggunakan uji Glejser dapat diketahui bahwa keempat variabel independen yaitu murabahah, mudharabah, ijarah dan NPF memiliki Uji Regresi Linier Berganda nilai signifikasi lebih dari 0,05 sehingga dapat ditarik kesimpulan bahwa tidak ada masalah heteroskedastisitas pada model regresi.

Tabel 7. Hasil Uji Regresi Linier Berganda

\begin{tabular}{ccc}
\hline Model & Unstandardized B & Coefficients Std. Error \\
\hline (Constant) & 2.891 & 0.795 \\
\hline Murabahah & -0.031 & 0.013 \\
\hline Mudharabah & 0.088 & 0.031 \\
\hline Ijarah & 0.005 & 0.034 \\
\hline NPF & -0.216 & 0.079
\end{tabular}

Sumber : Data Olahan (2021)

Dengan memperhatikan hasil $\quad \mathrm{Y}=2.891-0.031 \mathrm{X} 1+0.088 \mathrm{X} 2+0.005$ regresi maka dapat diperoleh persamaan $\quad \mathrm{X} 3-0.216 \mathrm{X} 4$ sebagai berikut :

\section{Uji Koefisien Determinasi $\left(\mathbf{R}^{2}\right)$}

Tabel 8. Hasil Uji Koefisien Determinasi

\begin{tabular}{cccc}
\hline Model & R & R Square & Adjusted R Square \\
\hline 1 & 0.679 & 0.486 & 0.396
\end{tabular}

Sumber : Data Olahan (2021)

Dari hasil perhitungan regresi diatas dapat dilihat dari jumlah sampel sebanyak 28 laporan keuangan didapatkan nilai $\mathrm{R}^{2}$ sejumlah 0,396 yang berarti variabel independen murabahah (X1), mudharabah (X2), ijarah (X3) dan NPF
(X4) menjelaskan variasi dari variabel dependen profitabilitas (Y) sebanyak $39,6 \%$. Sedangkan sisanya senilai $60,4 \%$ tingkat profitabilitas dipengaruhi oleh faktor lain diluar model. 
Uji Hipotesis Parsial (t)

Tabel 9. Hasil Uji Parsial

\begin{tabular}{cccc}
\hline Variabel & $\mathbf{t}_{\text {hitung }}$ & $\mathbf{t}_{\text {tabel }}$ & Sig \\
\hline Murabahah & -2.475 & 2.069 & 0.021 \\
\hline Mudharabah & 2.852 & 2.069 & 0.009 \\
\hline Ijarah & 0.152 & 2.069 & 0.880 \\
\hline NPF & -2.737 & 2.069 & 0.12 \\
\hline
\end{tabular}

Sumber : Data Olahan (2021)

Hasil regresi dari tabel diatas dapat dijelaskan sebagai berikut :

1) Hipotesis pertama menyatakan bahwa terdapat pengaruh signifikan antara pembiayaan murabahah terhadap profitabilitas. Dari hasil penelitian diperoleh nilai t-hitung sebesar -2.475 yang lebih besar dari nilai t-tabel 2.069, sehingga $\mathrm{Ha}_{1}$ diterima.

2) Hipotesis kedua menyatakan bahwa terdapat pengaruh signifikan antara pembiayaan mudharabah terhadap profitabilitas. Dari hasil penelitian diperoleh nilai t-hitung sebesar 2.852 yang lebih besar dari nilai t-tabel 2.069, sehingga $\mathrm{Ha}_{2}$ diterima.
3) Hipotesis ketiga menyatakan bahwa terdapat pengaruh signifikan antara pembiayaan ijarah terhadap profitabilitas. Dari hasil penelitian diperoleh nilai t-hitung sebesar 0.152 yang lebih kecil dari nilai t-tabel 2.069, sehingga $\mathrm{Ha}_{3}$ ditolak.

4) Hipotesis keempat menyatakan bahwa terdapat pengaruh signifikan antara rasio non performing financing terhadap profitabilitas. Dari hasil penelitian diperoleh nilai t-hitung sebesar -2.737 yang lebih besar dari nilai t-tabel 2.069, sehingga $\mathrm{Ha}_{4}$ diterima.

\section{Uji Hipotesis Simultan (F)}

Tabel 10. Hasil Uji Simultan

\begin{tabular}{cccc}
\hline Variabel & $\mathbf{f}_{\text {hitung }}$ & $\mathbf{f}_{\text {tabel }}$ & Sig \\
\hline Variabel Secara Simultan & 5.435 & 2.78 & 0.003 \\
\hline
\end{tabular}

Sumber : Data Olahan (2021)

Berdasarkan tabel 10 diketahui nilai t-hitung sebesar 5.435 yang mana lebih besar dari nilai t-tabel yaitu 2.78 , sehingga $\mathrm{Ha}_{5}$ diterima dan dapat disimpulkan bahwa pembiayaan murabahah, mudharabah, ijarah, dan rasio non performing financing secara simultan berpengaruh signifikan terhadap terhadap bank BRI syariah tahun 2014-2020.

\section{Pengaruh Pembiayaan Murabahah Terhadap Profitabilitas (ROA)}

Berdasarkan tabel 9 variabel pembiayaan murabahah mempunyai nilai signifikan $0,021<0,05$. Hal ini berarti menerima Ha atau menolak Ho sehingga dapat disimpulkan bahwa variabel pembiayaan murabahah secara parsial berpengaruh signifikan terhadap tingkat profitabilitas. Koefisien regresi untuk variabel pembiayaan murabahah memiliki tanda negatif, dapat disimpulkan, pendapatan murabahah yang semakin besar dapat menurunkan besarnya tingkat profitabilitas. Pembiayaan murabahah keuntungannya berbentuk margin penjualan yang didalamnya sudah termasuk harga jual. Sehingga apabila nasabah yang mendapatkan kredit dari bank syariah ini, tidak berkewajiban membayar cicilan beserta 
bunga pinjaman sekaligus. Pembayaran tersebut dapat dilakukan secara kredit. Pengelolaan yang mudah ini, memungkinkan bank syariah untuk meningkatkan kemampuannya dalam menghasilkan laba melalui pendapatan mark up yang bersumber dari pembiayaan jual beli yang disalurkan kepada masyarkat akan berpengaruh dalam meningkatkan profit. Oleh karena itu, pembiayaan ini dapat mempengaruhi profitabilitas (ROA), tetapi karena adanya percepatan pelunasan dalam pembiayaan murabahah sehingga profit yang dihasilkan kurang maksimal.

Hasil penelitian ini mendukung hasil penelitian yang dilakukan oleh Amalia (2016) yang menyatakan bahwa pembiayaan murabahah berpengaruh signifikan dan negatif terhadap tingkat profitabilitas. Namun hal ini bertolak belakang dengan penelitian Riyadi dan Yulianto (2014) yang menyatakan bahwa pembiayaan murabahah tidak berpengaruh signifikan terhadap profitabilitas.

\section{Pengaruh Pembiayaan Mudharabah Terhadap Profitabilitas (ROA)}

Berdasarkan tabel 9 variabel pembiayaan mudharabah mempunyai nilai signifikan $0,009<0,05$. Hal ini berarti menolak Ho atau menerima $\mathrm{Ha}$ sehingga dapat disimpulkan bahwa variabel pembiayaan mudharabah secara parsial berpengaruh signifikan terhadap tingkat profitabilitas.

Hal ini dikarenakan bahwa salah satu tujuan dari prinsip mudharabah merupakan pembagian keuntungan (nisbah) antara bank syariah dengan nasabah yang telah disepakati pada awal perjanjian. Keuntungan inilah yang akan menjadi pendapatan bagi bank syariah. Jadi hasil analisis diatas menunjukkan bahwa variabel pembiayaan mudharabah berpengaruh terhadap Profitabilitas pada PT. Bank BRI Syariah Tbk Tahun 2014-2020. Sehingga semakin tinggi pembiayaan mudharabah yang disalurkan maka semakin meningkatkan perolehan nisbah (bagi hasil) sehingga berpengaruh terhadap profitabilitas.

Hal tersebut sejalan dengan penelitian yang dilakukan oleh Pratama et al, (2017) yang menyatakan bahwa pembiayaan bagi hasil berpengaruh signifikan positif terhadap profitabilitas. Hasil penelitian ini juga mendukung hasil penelitian yang dilakukan oleh Amalia (2016) dan Azhar dan Nasim (2016) yang menyatakan bahwa pembiayaan mudharabah berpengaruh signifikan terhadap tingkat profitabilitas.

\section{Pengaruh Pembiayaan Ijarah Terhadap Profitabilitas (ROA)}

Berdasarkan tabel 9 variabel pembiayaan ijarah mempunyai nilai signifikan $0,880>0,05$. Hal ini berarti menerima Ho atau menolak Ha sehingga dapat disimpulkan bahwa variabel pembiayaan ijarah secara parsial tidak berpengaruh signifikan terhadap tingkat profitabilitas.

Hal ini disebabkan pembiayaan ijarah hasilnya yang tidak stabil bahkan cenderung menurun. Selain itu, dapat disebabkan oleh barang yang disewakan oleh pihak bank kepada nasabah akan memungkinkan terjadinya beberapa resiko diantaranya adanya kerusakan barang dan penyusutan barang yang mengakibatkan bank tetap mendapatkan biaya sewa namun harus menanggung kerusakan, biaya tambahan (perbaikan) dan mengalokasikan dana untuk biaya penyusutan barang.

Hal tersebut sejalan dengan penelitian yang dilakukan oleh Romdhoni \& Yozika (2018) dan Amalia (2016) yang menyatakan bahwa pembiayaan ijarah tidak berpengaruh terhadap profitabilitas Bank Muamalat Indonesia dan Bank Syariah Mandiri.

\section{Pengaruh Rasio Non Performing Financing Terhadap Profitabilitas (ROA)}

Berdasarkan tabel 9 variabel non performing financing mempunyai nilai signifikan $0,012<0,05$. Hal ini berarti menerima $\mathrm{Ha}$ atau menolak Ho sehingga 
dapat disimpulkan bahwa variabel non performing financing secara parsial berpengaruh signifikan terhadap tingkat profitabilitas.

Hal ini sesuai dengan teori Riyadi dan Yulianto (2014) yang menyatakan NPF erat kaitannya dengan pembiayaan yang disalurkan oleh bank syariah kepada nasabahnya. Apabila NPF menunjukkan nilai yang rendah diharapkan pendapatan akan meningkat sehingga laba yang dihasilkan akan meningkat, namun sebaliknya apabila nilai NPF tinggi maka pendapatan akan menurun sehingga laba yang didapat akan turun. Arah hubungan yang timbul antara NPF terhadap ROA adalah negatif, karena apabila NPF tinggi maka akan berakibat menurunnya pendapatan dan akan berpengaruh pada menurunnya ROA yang didapat oleh bank syariah.

Hal tersebut sejalan dengan penelitian yang dilakukan oleh Azhar dan Nasim (2016) dan Rahman \& Rochmanika (2012), yang menyatakan bahwa non performing financing berpengaruh signifikan terhadap profitabilitas.

\section{Pengaruh Pembiayaan Murabahah, Mudharabah, Ijarah dan Rasio Non Peforming Financing Terhadap Profitabilitas (ROA)}

Berdasarkan tabel 10 variabel pembiayaan murabahah, mudharabah, ijarah dan rasio non performing financing mempunyai nilai signifikan $0,000<0,05$. $\mathrm{Hal}$ ini berarti menerima $\mathrm{Ha}$ atau menolak Ho sehingga dapat disimpulkan bahwa variabel pembiayaan murabahah, mudharabah, ijarah dan rasio non performing financing secara simultan berpengaruh signifikan terhadap tingkat profitabilitas.

Hasil penelitian ini menunjukkan bahwa pembiayaan dan rasio non performing financing mempunyai peran penting dalam efisiensi perbankan syariah. Pembiayaan merupakan salah satu produk yang banyak diminati. Produk ini berupa penyaluran dana bank syariah atau pendanaan yang diberikan suatu pihak kepada pihak lain untuk mendukung investasi yang telah direncanakan baik dilakukan sendiri maupun lembaga. Komponen pembiayaan merupakan komoditas utama perbankan syariah dalam memperoleh keuntungan. Dimana keuntungan yang diperoleh perbankan akan menjamin kelangsungan usaha perbankan syariah di masa yang akan datang. Bank syariah menilai bahwa pembiayaan memiliki resiko tinggi dalam hal kerugian yang dapat terjadi dalam kurun waktu pembiayaan tersebut sehingga dapat menyebabkan turunnya laba suatu perusahaan. Pemberian pembiayaan merupakan aktifitas terbesar sekaligus mempunyai resiko terbesar (high risk high return). Menurut teori, semakin tinggi rasio Non Performing Financing (NPF), maka semakin buruk kualitas kredit bank yang menyebabkan jumlah kredit bermasalah semakin besar. Sehingga semakin tinggi rasio ini akan berpengaruh negatif terhadap profitabilitas Return on Asset (ROA) pada bank.

Hal ini sejalan dengan hasil penelitian terdahulu yang dilakukan oleh Azhar dan Nasim (2016) menunjukkan bahwa pembiayaan jual beli, pembiayaan bagi hasil dan NPF secara bersamaan berpengaruh terhadap profitabilitas yang diproksikan dengan Return on Asset pada Bank Umum Syariah Tahun 2012-2014.

\section{KESIMPULAN}

Hasil pengujian menunjukkan bahwa pembiayaan murabahah berpengaruh negatif terhadap profitabilitas yang diproksikan dengan Return on Asset. Oleh karena itu dinyatakan bahwa semakin tinggi nilai pembiayaan murabahah maka akan semakin menurunkan tingkat profitabilitas. Hasil pengujian menunjukkan bahwa pembiayaan mudharabah berpengaruh positif terhadap profitabilitas yang diproksikan dengan Return on Asset. Oleh karena itu dinyatakan bahwa semakin tinggi nilai pembiayaan mudharabah maka akan semakin meningkatkan tingkat profitabilitas. Hasil pengujian menunjukkan bahwa pembiayaan ijarah tidak berpengaruh terhadap 
profitabilitas yang diproksikan dengan Return on Asset. Oleh karena itu pembiayaan ijarah tidak menjadi salah satu faktor dalam profitabilitas pada PT. Bank BRI Syariah Tbk Tahun 2014-2020. Hasil pengujian menunjukkan bahwa non performing financing berpengaruh negatif terhadap profitabilitas yang diproksikan dengan Return on Asset. Oleh karena itu dinyatakan bahwa semakin tinggi nilai NPF maka akan semakin menurunkan tingkat profitabilitas. Hasil pengujian menunjukkan bahwa pembiayaan murabahah, mudharabah, ijarah dan NPF secara bersamaan berpengaruh terhadap profitabilitas yang diproksikan dengan Return on Asset sebesar $39,6 \%$.

\section{DAFTAR PUSTAKA}

Amalia, Nur. 2016. Struktur Pembiayaan dan Pengaruhnya Terhadap Profitabilitas Bank Muamalat Indonesia dan Bank Syariah Mandiri. Jurnal Ilmu Dan Riset Akuntansi, 5(5), p.1-16.

Azhar, Ian., \& Nasim, Aarim. 2016. Pengaruh Pembiayaan Jual Beli, Pembiayaan Bagi Hasil, Dan Non Performing Finance Terhadap Profitabilitas (Studi Kasus Pada Bank Umum Syariah Di Indonesia Periode 2012 - 2014). Jurnal ASET (Akuntansi Riset), 8(1), p. 61-76.

Basuki, Nano Prawoto. 2016. Analisis Regresi dalam Penelitian Ekonomi \& Bisnis: Dilengkapi Aplikasi SPSS \& Eviews. Rajawali Pers. Jakarta.

Ghazali, Imam. 2013. Aplikasi Analisis Multivariance Dengan Program IBM SPSS 21. Badan Penerbit Universitas Diponegoro. Semarang.

Karim, Adiwarman. 2014. Bank Islam Analisis Fiqih dan Keuangan. PT. Raja Grafindo Persada. Jakarta.

Kasmir. 2014. Bank dan Lembaga Keuangan Lainnnya. Rajawali Press. Jakarta.

Lestari, Winda. 2017. Pengaruh Pembiayaan Mudharabah, Pembiayaan Musyarakah, Pembiayaan Murabahah, Financing To
Deposit Ratio (FDR), Non Performing Financing (NPF) Dan Market Share Terhadap Profitabilitas (Studi Pada Bank Umum Syariah Di Indonesia Periode 2011-2016). Skripsi, Fakultas Ekonomi dan Ilmu Sosial, Universitas Islam Nenegri Sultan Syarif Kasim Riau.

Ma'isyah, Rifqul., \& Mawardi, Imron. 2015. Pengaruh Kecukupan Modal, Fungsi Intermediasi, Efisiensi Operasional, Dan Pembiayaan Bermasalah Terhadap Profitabilitas (Studi pada Bank Syariah Periode Januari 2010-Juli 2014). JESIT, 2(3), p. 249-265.

Muhammad. 2016. Manajemen Pembiayaan Bank Syariah. UPP STIM YKPN. Yogyakarta.

Pratama, Ditha Nanda., Martika, Lia Dwi., \& Rahmawati, Teti. 2017. Pengaruh Pembiayaan Mudharabah, Pembiayaan Musyarakah dan Sewa Ijarah Terhadap Profitabilitas. Jurnal Riset Keuangan dan Akuntansi, 3(1), p. 53-68.

Pratiwi, Dhian Dayinta. 2012. Pengaruh CAR, BOPO, NPF dan FDR Terhadap Return On Asset (ROA) Bank Umum Syariah. Skripsi, Fakultas Ekonomi, Univeristas Diponegoro.

Rahman, Aulia Fuad., \& Rochmanika, Ridha. 2012. Pengaruh Pembiayaan Jual Beli, Pembiayaan Bagi Hasil, Dan Rasio Non Performing Financing Terhadap Profitabilitas Bank Umum Syariah di Indonesia. Iqtishoduna, 8(1), p. 1-16.

Riyadi, Slamet., dan Yulianto, Agung. 2014. Pengaruh Pembiayaan Bagi Hasil, Pembiayaan Jual Beli, Financing To Deposit Ratio (FDR) Dan Non Performing Financing (NPF) Terhadap Profitabilitas Bank Umum Syariah Di Indonesia. Accounting Analysis Journal, 3(4), p. 466-474.

Romdhoni, Abul Haris., \& El Yozika, Ferlangga. 2018. Pengaruh Pembiayaan Mudharabah, Musyarakah dan Ijarah 
Terhadap Profitabilitas Bank Muamalat Indonesia. Jurnal Ilmiah Ekonomi Islam, 4(03), p.177-186.

Satriawan, Aditya., \& Arifin, Zainul. 2016. Analisis Profitabilitas Dari Pembiayaan Mudharabah, Musyarakah, Dan Murabahah Pada Bank Umum Syariah Di Indonesia Periode 2005-2010. Media Riset Akuntansi, Auditing Dan Informasi, 12(1), p. 1-22.

Suharyadi, Purwanto. 2011. Statistika: Untuk Ekonomi dan Keuangan Modern. Salemba Empat. Jakarta.

Sujarweni, V. Wiratna. 2015. Metodologi Penelitian Bisnis Ekonomi. Pustaka Baru Press. Yogyakarta.

Umam, Khareul. 2013. Manajemen Perbankan Syariah. Pustaka Setia. Bandung.

Vanni, Kartika Marella., \& Rokhman, Wahibur. 2017. Analisis Faktor-Faktor Yang Mempengaruhi Non Performing Financing Pada Perbankan Syariah Di Indonesia Tahun 2011-2016. EQUILIBRIUM, 5(2), p. 306-319.

Yustati, Herlina., \& Handayani, Lidian Disfa.2017 Strategi Perbankan Syariah Dalam Menyokong Indonesia Menjadi Trend Setter Industri Halal. Baabu AlIlmi, 2(1),p. 16-35.

Zainuddin. 2010. Hukum Perbankan Syariah. Sinar Grafika. Jakarta. 